African Crop Science Journal by African Crop Science Society is licensed under a Creative Commons Attribution 3.0 Uganda License. Based on a work at www.ajol.info/ and www.bioline.org.br/cs DOI: http://dx.doi.org/10.4314/acsj.v24i1.1S

\title{
LEVERAGING FROM GENOTYPE BY ENVIRONMENT INTERACTION FOR BREAD WHEAT PRODUCTION IN EASTERN AFRICA
}

\author{
T. ZERIHUN, A. DAWIT, Z. HABTEMARIAM, P. NJAU ${ }^{1}$ and R. MONGI ${ }^{2}$ \\ Ethiopian Institute of Agricultural Research (EIAR), P. O. Box 2003, Addis Ababa, Ethiopia \\ ${ }^{1}$ Kenya Agricultural and Livestock Research Organization-Njoro, Private Bag (20107), Njoro, Kenya \\ ${ }^{2}$ Uyole Agricultural Research Institute, Ministry of Agriculture, P. O. Box 400, Mbeya, Tanzania \\ Corresponding author: zerbest2008@gmail.com
}

\begin{abstract}
Developing high yielding and stable genotypes for wide and specific adaptation is important in wheat (Triticum aestivum L.) production. The objective of this study was to exploit the gains from genotype by environment interaction for increased bread wheat production in eastern Africa. Thirty-three advanced bread wheat lines, along with two check varieties (Danda'a and Hidasse) were evaluated at ten locations in Ethiopia and Kenya. The experiment was laid out in alpha lattice design in three replications. The analysis of variance for AMMI model of grain yield showed that environment, genotypes and genotype by environment interaction (GEI) effects were highly significant $(\mathrm{P}<0.01)$, and accounted for $62.4,4.8$ and $15.8 \%$ of the total sum of squares variations, respectively. High environmental and significant GEI indicated that the environment had major influence for inconsistent performance. Grain yield of the genotypes ranged from $1.58 \mathrm{t} \mathrm{ha}^{-1}$ (G30) to $9.05 \mathrm{t} \mathrm{ha}^{-1}$ (G31). Genotypes G31, G18 and G35 were the best performing lines across environments. The AMMI biplot, using the first two principal components, showed that testing sites Njoro and Arsi-Robe highly discriminated the tested genotypes. Njoro was negatively interacting with high yielding genotypes, and was a different environment from any of the testing locations of Ethiopia for these sets of genotypes. It may be difficult to develop high yielding and stable varieties for the two countries, but one should look for specific adaptation. Genotypes G31 and G18 produced high grain yield, with low stability across locations which were favouring high yielding environments. However, G21 and G8 had above mean grain yield and good stability across locations. Therefore, wheat breeding for specific adaptability is very important to exploit the genetic advantage of specific genotypic performances across the region. However, extensive testing considering many locations across East African countries is vital for delineating and exploiting wheat environments for marked developments.
\end{abstract}

Key Words: AMMI, GEI, Triticum aestivum

\section{RÉSUMÉ}

Le développement de variétés stables et a rendements élevés dans le but d'adoption a grande échelle, est important dans la production du blé tendre (Triticum aestivum L.). L'objectif de cette étude est d'exploiter l'effet de l'interaction entre génotypes et environnements (IGE) pour accroitre la production du blé tendre en Afrique de l'Est. Trente-trois lignées avancées de blé tendre ensemble avec deux variétés de référence (Danda'a and Hidasse) ont été évaluées dans dix locations. Le plan expérimental était en treillis alpha avec trois répétitions. La méthode de l'interaction des effets additifs and multiplicative (AMMI) avait été utilisée pour le rendement en grain. L'analyse des variances selon ce modèle a montré que l'environnement, le génotype et l'interaction des deux ont des effets significatifs sur le rendement en grains $(\mathrm{P}<0,01)$, et contribuent respectivement, 62,$4 ; 4,8$ et $15,8 \%$ à la variation totale. Un effet important de l'environnement et une interaction significative indiquent que l'environnement a un rôle majeur dans les différences de rendements. Les rendements en grains des génotypes testes varient de $1.58 \mathrm{tha}^{-1}$ (G30) a $9.05 \mathrm{t} \mathrm{ha}^{-1}$ (G31). Les génotypes G31, G18 et G35 étaient de façon générale, 
les plus performants. Le biplot génère par AMMI a montré que les sites Njoro and Arsi-Robe discriminent nettement les génotypes testés. Njoro était négativement corrélé avec les génotypes a rendement élevé et constituait un environnement différent de toutes les autres locations de l'Ethiopie ou ces génotypes ont été testes. Il peut s'avérer difficile de développer des variétés à haut rendement et stable dans les deux pays, mais l'on doit rechercher des variétés adaptées à chaque milieu. Les génotypes G31 et G18 ont eu des rendements élevés mais n'ont pas été stables dans les milieux qui se sont avérés à haut rendement. Néanmoins, G21 et G8 ont eu des rendements plus élevés que la moyenne et se sont montres stables d'un milieu à un autre. Il s'ensuit donc que le développement de variété de blé tendre adapté à chaque milieu serait une bonne approche pour une exploitation efficiente des avantages génétiques des génotypes à haute performance. Néanmoins, il est important de faire des essais extensifs prenant en compte plusieurs localités des pays de l'Afrique de l'Est afin d'explorer et identifier les milieux propices au blé tendre.

Mots Clés: AMMI, IGE, Triticum aestivum

\section{INTRODUCTION}

Wheat (Triticum aestivum L.) is grown worldwide on roughly 200 million hectares, with average total production of 700 million metric tonnes (FAOSTAT, 2014). Global average productivity is around $3 \mathrm{t} \mathrm{ha}^{-1}$, with high variability among countries and regions. It is the most important food grain for humans, supplying $40 \%$ of the world's food and $25 \%$ of calories consumed in developing countries. In Eastern Africa, wheat is one of the most important cereal crops cultivated in a wide range of agro-ecologies. Despite the enormous economic and dietary values of the crop in the region, the average yield has remained extremely low. This has been attributed to multifaceted biotic and abiotic factors, including insufficient and erratic rainfall, poor agronomic practices, poor soil fertility, diseases and insect pests (Hailu et al., 1991).

The development of cultivars or varieties, which can be adapted to a wide range of environments, is the ultimate goal of plant breeders in a crop improvement programme. The adaptability of a variety over diverse environments is usually tested by the degree of its interaction with different environments. A variety or genotype is considered to be more adaptive or stable if it has a high mean yield, but with a low degree of fluctuation in yielding ability when grown in diverse environments. Hence, the genotype-by-environment interaction is probably the main reason why traditional plant breeding failed to develop widely adaptable varieties (Ceccarelli et al., 2003). Developing high yielding and stable genotypes for wide and specific adaptation are important in wheat variety development strategies, and evaluation across locations would form a basis for breeding. The objective of this study was to exploit the gains from genotype by environment interaction for increased bread wheat production in eastern Africa.

\section{MATERIALS AND METHODS}

Thirty three bread wheat advanced lines (Table 1), along with two check varieties (Danda' a and Hidasse) were evaluated in different locations of Ethiopia (9 location) and Kenya (1 location), during 2013/2014 main cropping seasons (Table 2 ). These locations represent the major wheat growing agro-ecologies of the two countries ranging from mid to high altitude. The genotypes were planted in alpha lattice $(5 \times 7)$, with three replications in all experimental sites. Each plot had six rows of $2.5 \mathrm{~m}$ length, with a spacing of 0.2 $\mathrm{m}$ between rows and $3-5 \mathrm{~cm}$ within rows. Planting date of each location was at the onset of the main rainy season. Fertiliser and other agronomic practices were carried out as per the recommendation of each location. Grain yield data were collected from the middle four rows and measured after moisture of the seed is adjusted to $12.5 \%$.

Statistical analysis. Separate analysis of variance for grain yield, for each location, was performed prior to combined analysis using AGROBASE 20 (Agronomix Software Inc., 1999). The mean squares of genotype by environment interactions (GEI) for grain yield were used to test the effect 
TABLE 1. Bread wheat genotypes evaluated across ten locations in 2013/2014 cropping seasons in eastern Africa

\begin{tabular}{|c|c|c|}
\hline Code & Designation & Pedigree \\
\hline G1 & Danda'a & KIRITATI//2*PBW65/2*SERI.1B \\
\hline G2 & ETBW 6832 & CNO79//PF70354/MUS/3/PASTOR/4/BAV92*2/5/HAR311 \\
\hline G3 & ETBW 6837 & CNO79//PF70354/MUS/3/PASTOR/4/BAV92*2/5/FH6-1-7 \\
\hline G4 & ETBW 6839 & $\begin{array}{l}\mathrm{CAL} / \mathrm{NH} / / \mathrm{H} 567.71 / 3 / \mathrm{SERI} / 4 / \mathrm{CAL} / \mathrm{NH} / / \mathrm{H} 567.71 / 5 / 2^{*} \mathrm{KAUZ} / 6 / \mathrm{PASTOR} / 7 / \mathrm{YANAC} / 8 / \mathrm{CAL} / \mathrm{NH} / / \\
\mathrm{H} 567.71 / 3 / \mathrm{SERI} / 4 / \mathrm{CAL} / \mathrm{NH} / / \mathrm{H} 567.71 / 5 / 2^{*} \mathrm{KAUZ} / 6 / \mathrm{PASTOR}\end{array}$ \\
\hline G5 & ETBW 6840 & $\mathrm{PRL} / 2^{*} \mathrm{PASTOR}{ }^{*} 2 / / \mathrm{FH} 6-1-7$ \\
\hline G6 & ETBW 6841 & PBW343*2/KUKUNA*2//FRTL/PIFED \\
\hline G7 & ETBW 6845 & ATTILA*2/PBW65*2//MURGA \\
\hline G8 & ETBW 6847 & ROLF07*2/5/REH/HARE//2*BCN/3/CROC_1/AE.SQUARROSA (213)//PGO/4/HUITES \\
\hline G9 & ETBW 6848 & ROLF07*2/5/FCT/3/GOV/AZ//MUS/4/DOVE/BUC \\
\hline G10 & ETBW 6850 & FRNCLN/ROLF07 \\
\hline G11 & ETBW 6852 & ROLF07/MUU \\
\hline G12 & ETBW 6853 & BECARD/5/PGO//CROC_1/AE.SQUARROSA (224)/3/2*BORL95/4/CIRCUS \\
\hline G13 & ETBW 6861 & WAXWING*2/HEILO \\
\hline G14 & ETBW 6862 & KIRITATI/4/2*BAV92//IRENA/KAUZ/3/HUITES \\
\hline G15 & ETBW 6866 & KLDR/PEWIT1//MILAN/DUCULA \\
\hline G16 & ETBW 6869 & MURGA//WAXWING/KIRITATI \\
\hline G17 & ETBW 6870 & ATTILA*2/PBW65//MURGA \\
\hline G18 & ETBW 6871 & ROLF07*2/4/CROC_1/AE.SQUARROSA (205)//BORL95/3/2*MILAN \\
\hline G19 & ETBW 6875 & WAXWING/KIRITATI*2//YANAC \\
\hline G20 & ETBW 6876 & CNO79//PF70354/MUS/3/PASTOR/4/BAV92*2/5/HAR311 \\
\hline G21 & ETBW 6882 & $\mathrm{PRL} / 2^{*} \mathrm{PASTOR}{ }^{*} 2 / / \mathrm{FH} 6-1-7$ \\
\hline G22 & ETBW 6883 & FINSI/METSO//FH6-1-7/3/FINSI/METSO \\
\hline G23 & ETBW 6886 & $\begin{array}{l}\text { KAUZ/PASTOR//PBW343/3/HAR311/5/OASIS/SKAUZ//4*BCN/3/PASTOR/4/KAUZ*2/YACO// } \\
\text { KAUZ }\end{array}$ \\
\hline G24 & ETBW 6890 & ATTILA*2/PBW65*2//MURGA \\
\hline G25 & ETBW 6911 & REH/HARE//2*BCN/3/CROC_1/AE.SQUARROSA (213)//PGO/4/HUITES/5/PVN \\
\hline G26 & ETBW 6921 & 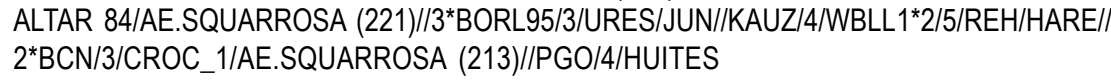 \\
\hline G27 & ETBW 6928 & KIRITATI/4/2*BAV92//IRENA/KAUZ/3/HUITES \\
\hline G28 & ETBW 6932 & SKAUZ/BAV92//2*WBLL1*2/KKTS \\
\hline G29 & ETBW 6937 & AGUILAL/FLAG-3 \\
\hline G30 & ETBW 6939 & UTIQUE 96/FLAG-1 \\
\hline G31 & ETBW 6943 & SKAUZ/BAV92/3/CROC-1/AE.SQUARROSA (224)//OPATA \\
\hline G32 & ETBW 6947 & WON-D 82/3/NS732/HER//KAUZ'S'=(FIDIYA-26) \\
\hline G33 & ETBW 6948 & REBWAH-12/ZEMAMRA-8 \\
\hline G34 & ETBW 6953 & CROW'S'/BOW'S' -3-1994/95//TEVEE'S'/TADINIA \\
\hline G35 & Hidasse & YANAC/3/PRL/SARA//TSI/VEE\#5/4 \\
\hline
\end{tabular}

ETBW $=$ Ethiopian Bread Wheat 
TABLE 2. Description of the test locations for the wheat regional trial in eastern Africa

\begin{tabular}{|c|c|c|c|c|}
\hline Location & Location code & Altitude (m.a.s.l) & Annual R.F (mm) & Representing agro-ecology \\
\hline ADET & $A D$ & 2240 & 869 & Optimum5 area \\
\hline AREKA/ANGACHA & AR & 2400 & 1656 & Optimum area \\
\hline BEKOJI & BK & 2780 & 1020 & Optimum and high RF area \\
\hline HOLETTA & $\mathrm{HO}$ & 2400 & 1100 & Optimum area \\
\hline JAMA & JM & 2600 & - & Low potential area \\
\hline KULUMSA & KU & 2200 & 820 & Optimum area \\
\hline MEHONI & $\mathrm{MH}$ & 1754 & 500 & Low potential area \\
\hline NJORO & NJ & 2120 & - & Optimum area \\
\hline SINANA & $\mathrm{SN}$ & 2400 & 950 & Optimum area \\
\hline WUKRO & WK & 2020 & 646.6 & Optimum area \\
\hline
\end{tabular}

of genotypes. The genotypes (G) and environments (E) were subjected to AMMI analysis (Gauch and Zobel, 1997). The bi-plot constructed from main effect of means $v s$ the first Interaction Principal Component Analysis Axis (IPCA) from AMMI analysis, was used to study the pattern of response of G, E and GEI. It was also used to identify genotypes with broad or specific adaptation to target environments for grain yield. AMMI-II biplot was constructed in the dimension of first two IPCA, using a singularvalue decomposition procedure (Yan et al., 2000). The genotypes were represented on the biplots as the points derived from their scores and the environments as the vectors from the biplot origin to their points. IRRISTAT (IRRI, 2005) was used to construct AMMI-1 and AMMI-2 biplot (Zobel et al., 1988).

The equation for AMMI model is:

$Y_{i j}=\mu+G_{i}+E_{j}+\sum_{n=1}^{N} \lambda_{n} \alpha_{i n} \gamma_{j n}+e_{i j}$

Where:

$Y_{i j}$ is the yield of the $i^{\text {th }}$ genotype in the $j^{\text {th }}$ environment; $\mu$ is the grand mean; $G_{i}$ and $E_{i}$ are the genotype and environment deviations from the grand mean, respectively; $\lambda_{n}$ is the eigen value of the PCA axis $n ; \alpha_{\text {in }}$ and $\gamma_{\text {in }}$ are the genotype and environment principal component scores for axis $\mathrm{n}$, respectively; $\mathrm{N}$ is the number of principal components retained in the model and $\mathrm{e}_{\mathrm{ij}}$ is the error term.
AMMI model does not make provision for a specific stability measure to be determined; such a measure is essential in order to quantify and rank genotypes according to their yield stability. Since the IPCA-1 score contributes more to GEI sum of squares, it has to be weighted by the proportional difference between IPCA-1 and IPCA-2 scores to compensate for the relative contribution of IPCA-1 and IPCA-2 in to the total GEI sum of squares called AMMI stability values (ASV). The following measure proposed by Purchase (2000) was used:

$$
\begin{aligned}
& A S V= \\
& \sqrt{\left[\frac{I P C A 1 \text { sum of squares (IPCA } 1 \text { score })}{I P C A 2 \text { sum of squares }}\right]^{2}} \\
& +(\text { IPCA } 2 \text { score })^{2}
\end{aligned}
$$

\section{RESULT AND DISCUSSION}

Pooled analysis of variance for grain yield showed highly significant $(\mathrm{P}<0.05)$ differences among genotypes, environment and genotype by environment interaction (Table 3). Highly significant differences between the $\mathrm{G}$ and $\mathrm{E}$ for grain yield indicate the presence of genetic variability among the genotypes, as well as the environments under study. The mean yield of genotypes across environment ranged from 1.58 tha $^{-1}$ (G30) to 9.05 tha $^{-1}(\mathrm{G} 31)$. The environmental index range from $2.30 \mathrm{tha}^{-1}$ (JAMA) to $6.93 \mathrm{t}$ 
TABLE 3. AMMl analysis of variance for grain yield $\left(\mathrm{tha}^{-1}\right)$ of 35 genotypes tested ten locations of Ethiopia and Kenya

\begin{tabular}{|c|c|c|c|c|c|c|}
\hline \multirow[t]{2}{*}{ Source } & \multirow[t]{2}{*}{ Df } & \multirow[t]{2}{*}{ SS } & \multirow[t]{2}{*}{ MS } & \multicolumn{3}{|c|}{ Sum of square explained (\%) } \\
\hline & & & & $\begin{array}{c}\text { Total } \\
\text { variation }\end{array}$ & $\begin{array}{c}G \times E \\
\text { explained }\end{array}$ & $\begin{array}{c}\mathrm{G} \times \mathrm{E} \\
\text { cumulative }\end{array}$ \\
\hline Environments & 9 & 1459.185 & $162.132^{\star * *}$ & 62.4 & & \\
\hline Reps within Env. & 20 & 31.943 & 1.597 & 1.4 & & \\
\hline Genotype & 34 & 112.089 & $3.297^{* * *}$ & 4.8 & & \\
\hline Genotype x Env. & 306 & 370.546 & $1.211^{* * *}$ & 15.8 & & \\
\hline IPCA 1 & 42 & 122.74 & $2.922^{\star * *}$ & & 33.12 & 33.12 \\
\hline IPCA 2 & 40 & 71.975 & $1.799^{\star * \star}$ & & 19.42 & 52.55 \\
\hline IPCA 3 & 38 & 64.437 & $1.696^{* \star *}$ & & 17.39 & 69.94 \\
\hline IPCA 4 & 36 & 40.161 & $1.116^{\star * *}$ & & 10.84 & 80.78 \\
\hline IPCA 5 & 34 & 24.277 & $0.714^{\mathrm{ns}}$ & & 6.55 & 87.33 \\
\hline IPCA 6 & 32 & 19.454 & $0.608^{\mathrm{ns}}$ & & 5.25 & 92.58 \\
\hline IPCA 7 & 30 & 12.241 & $0.408^{\text {ns }}$ & & 3.30 & 95.88 \\
\hline IPCA 8 & 28 & 9.278 & $0.331^{\mathrm{ns}}$ & & 2.50 & 98.39 \\
\hline IPCA 9 & 26 & 5.983 & $0.230^{\mathrm{ns}}$ & & 1.61 & 100 \\
\hline Residual & 680 & 364.419 & 0.536 & 15.6 & & \\
\hline Total & 1049 & 2338.182 & & & & \\
\hline \multicolumn{2}{|c|}{ Grand Mean $=4.12 \mathrm{t} \mathrm{ha}^{-1}$} & R-squared $=0.84$ & C.V $=17.7 \%$ & \multicolumn{2}{|c|}{$\operatorname{LSD}(5 \%)=0.37$} & \\
\hline
\end{tabular}

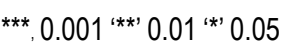

${ }^{* * *}=$ significant at $\mathrm{P}<0.001$ and $n s=$ non-significant; IPCA = Interaction principal component axis

ha $^{-1}$ (BEKOJI) (Table 4). Significant GEI suggest a linier function of the additive environment effects, and was reflected by the change in the ranking order of genotypes under varying environments. Similar results were reported by earlier authors (Amin et al., 2005; Ali, 2006; Cotes et al., 2006). However, the overall performance of the genotypes depends upon the magnitude of GEI.

The highest grain yield over environments was recorded from BEKOJI location from G31, G21 and G5, respectively (Table 4). The standard check variety G35 (Hidasse) remained the third highest yielder over all locations; followed by G31 and G18. This revealed least two promising genotypes, better than the standard check based on grain yield potential across locations. Whereas, the other check, G1 (Danda'a), ranked $20^{\text {th }}$ with a grain yield of $4.04 \mathrm{t} \mathrm{ha}^{-1}$. BEKOJI, AREKA and KULUMSA were among the first three high yielding locations; while JAMA, WUKRO and SINANA were the lowest yielding environments.
Location tested in Kenya (NJORO) recorded average yield of $4.03 \mathrm{tha}^{-1}$, which was near to the grand total mean $4.12 \mathrm{t} \mathrm{ha}^{-1}$ (Table 4). From the total treatment sum of square of the model, $62.4 \%$ was attributed to environmental effects, and the rest to genotypic effects $(4.8 \%)$ and GEI $(15.8 \%)$ (Table 3). The highly significant mean squares of environment, indicated that the environments were diverse, with large differences among means, causing most of the variation in grain yield. This shows the predominant influence of environments on the yield performance of wheat genotypes.

The GEI component of variation was partitioned into nine possible interaction principal component axes (IPCA) (Fig. 1). The F-test indicated that only the first four IPCA were highly significant $(\mathrm{P}<0.01)$ (Table 3). The first four significant IPCA explained $80.8 \%$ of the total GEI sum of square; while the remaining IPCA explained only $19.2 \%$. Therefore, the first four significant IPCA can be taken as adequate dimensions for this dataset. However, the 
TABLE 4. Mean grain yield ( $\left(\right.$ ha $\left.^{-1}\right)$ of 35 genotypes tested across ten locations of Ethiopia and Kenya

\begin{tabular}{|c|c|c|c|c|c|c|c|c|c|c|c|c|c|c|c|c|}
\hline Genotypes & $\mathrm{KU}$ & $A D$ & AR & BK & JMA & WK & $\mathrm{MH}$ & NJ & SN & $\mathrm{HO}$ & Gen mean & Rank & IPCA-1 & IPCA-2 & ASV & Rank \\
\hline G1 & 4.20 & 3.46 & 5.27 & 7.37 & 2.40 & 2.49 & 4.73 & 4.05 & 3.40 & 2.85 & 4.04 & 20 & -0.182 & -0.250 & 0.399 & 9 \\
\hline G2 & 4.92 & 3.54 & 4.23 & 6.42 & 2.13 & 2.87 & 4.06 & 4.99 & 4.15 & 3.90 & 4.18 & 15 & -0.319 & 0.458 & 0.711 & 18 \\
\hline G3 & 3.51 & 3.49 & 4.73 & 5.93 & 2.71 & 2.96 & 4.90 & 4.08 & 3.31 & 3.02 & 3.93 & 22 & -0.465 & -0.332 & 0.860 & 25 \\
\hline G4 & 4.43 & 3.90 & 5.37 & 5.85 & 2.06 & 2.78 & 4.23 & 3.53 & 3.54 & 2.98 & 3.9 & 25 & -0.135 & -0.391 & 0.454 & 12 \\
\hline G5 & 4.38 & 4.69 & 5.87 & 8.45 & 2.18 & 3.03 & 3.88 & 3.17 & 3.69 & 4.39 & 4.44 & 9 & 0.723 & -0.211 & 1.251 & 30 \\
\hline G6 & 4.34 & 3.77 & 4.45 & 6.02 & 2.62 & 3.17 & 3.97 & 4.41 & 2.94 & 2.58 & 3.89 & 27 & -0.498 & -0.157 & 0.864 & 26 \\
\hline G7 & 4.75 & 3.96 & 3.73 & 6.80 & 2.50 & 2.91 & 5.29 & 5.99 & 3.23 & 4.33 & 4.28 & 12 & -0.667 & 0.723 & 1.348 & 33 \\
\hline G8 & 5.70 & 4.45 & 4.30 & 7.04 & 2.45 & 3.27 & 4.13 & 3.87 & 4.62 & 4.00 & 4.51 & 6 & 0.104 & 0.335 & 0.379 & 8 \\
\hline G9 & 4.48 & 4.21 & 4.10 & 5.81 & 1.96 & 2.50 & 5.47 & 4.41 & 3.28 & 3.37 & 4.07 & 19 & -0.521 & 0.145 & 0.900 & 27 \\
\hline $\mathrm{G} 10$ & 5.39 & 4.11 & 5.59 & 6.68 & 3.00 & 2.83 & 4.12 & 3.75 & 3.75 & 2.42 & 4.19 & 14 & -0.053 & -0.420 & 0.430 & 10 \\
\hline G11 & 3.02 & 3.95 & 6.12 & 6.36 & 2.28 & 3.23 & 4.27 & 2.70 & 2.59 & 1.61 & 3.57 & 34 & -0.044 & -1.276 & 1.278 & 31 \\
\hline $\mathrm{G} 12$ & 4.86 & 4.09 & 5.04 & 6.69 & 1.71 & 2.90 & 3.82 & 4.13 & 3.47 & 2.50 & 3.91 & 24 & -0.112 & -0.185 & 0.266 & 6 \\
\hline $\mathrm{G} 13$ & 6.08 & 4.60 & 5.48 & 8.30 & 2.26 & 2.75 & 3.81 & 2.05 & 4.49 & 4.96 & 4.44 & 8 & 1.108 & 0.169 & 1.897 & 35 \\
\hline G14 & 3.05 & 3.92 & 4.20 & 5.49 & 2.67 & 3.01 & 4.52 & 3.57 & 3.74 & 3.78 & 3.92 & 23 & -0.349 & -0.209 & 0.631 & 15 \\
\hline G15 & 4.60 & 4.10 & 5.22 & 7.09 & 1.89 & 3.09 & 3.29 & 5.00 & 3.14 & 3.66 & 4.11 & 18 & -0.097 & 0.106 & 0.196 & 4 \\
\hline $\mathrm{G} 16$ & 3.43 & 3.58 & 3.51 & 6.42 & 1.94 & 3.21 & 4.54 & 4.07 & 2.37 & 4.13 & 3.64 & 33 & -0.322 & 0.308 & 0.630 & 14 \\
\hline G17 & 3.99 & 3.54 & 4.96 & 6.47 & 2.13 & 2.53 & 3.35 & 4.56 & 3.25 & 3.17 & 3.77 & 31 & -0.190 & -0.044 & 0.327 & 7 \\
\hline $\mathrm{G} 18$ & 4.09 & 4.77 & 6.11 & 7.94 & 3.17 & 2.71 & 4.35 & 4.12 & 4.30 & 5.60 & 4.59 & 2 & 0.467 & -0.027 & 0.797 & 21 \\
\hline G19 & 6.00 & 4.22 & 5.33 & 6.78 & 2.49 & 2.92 & 4.00 & 5.76 & 3.59 & 3.87 & 4.48 & 7 & -0.347 & 0.375 & 0.701 & 17 \\
\hline G20 & 5.41 & 3.58 & 4.05 & 6.09 & 2.20 & 2.85 & 4.33 & 4.97 & 3.71 & 3.90 & 4.13 & 16 & -0.435 & 0.553 & 0.925 & 28 \\
\hline G21 & 4.80 & 4.64 & 4.76 & 8.67 & 2.61 & 2.39 & 5.43 & 4.35 & 3.63 & 4.35 & 4.54 & 5 & 0.275 & 0.321 & 0.568 & 13 \\
\hline G22 & 3.57 & 4.10 & 4.76 & 6.55 & 2.10 & 2.77 & 4.55 & 3.91 & 2.99 & 4.68 & 4.03 & 21 & -0.032 & 0.077 & 0.094 & 2 \\
\hline $\mathrm{G} 23$ & 4.79 & 4.20 & 6.52 & 7.35 & 1.78 & 2.72 & 4.76 & 3.42 & 4.49 & 3.50 & 4.28 & 13 & 0.386 & -0.501 & 0.827 & 23 \\
\hline G24 & 4.77 & 3.59 & 3.86 & 6.75 & 2.21 & 2.29 & 3.68 & 4.81 & 3.13 & 3.74 & 3.89 & 26 & -0.218 & 0.577 & 0.686 & 16 \\
\hline G25 & 4.13 & 3.75 & 5.42 & 8.35 & 2.57 & 3.06 & 3.90 & 4.30 & 4.71 & 4.72 & 4.55 & 4 & 0.423 & 0.125 & 0.732 & 20 \\
\hline G26 & 5.12 & 3.98 & 5.42 & 7.07 & 2.04 & 2.81 & 5.27 & 4.30 & 3.67 & 3.54 & 4.31 & 11 & -0.075 & -0.046 & 0.136 & 3 \\
\hline $\mathrm{G} 27$ & 2.91 & 4.27 & 5.09 & 5.96 & 2.43 & 3.46 & 4.19 & 4.22 & 3.49 & 3.26 & 3.85 & 29 & -0.392 & -0.523 & 0.849 & 24 \\
\hline $\mathrm{G} 28$ & 4.58 & 4.42 & 5.25 & 7.14 & 1.98 & 2.98 & 3.45 & 3.69 & 3.97 & 3.31 & 4.13 & 17 & 0.231 & -0.187 & 0.436 & 11 \\
\hline G29 & 5.44 & 3.63 & 4.77 & 8.39 & 2.61 & 2.42 & 4.26 & 2.32 & 4.33 & 5.11 & 4.39 & 10 & 0.940 & 0.402 & 1.653 & 34 \\
\hline G30 & 5.23 & 3.74 & 4.64 & 5.99 & 1.58 & 2.20 & 4.56 & 3.04 & 3.02 & 3.20 & 3.85 & 30 & 0.025 & 0.032 & 0.053 & 1 \\
\hline G31 & 4.38 & 4.54 & 5.36 & 9.05 & 3.15 & 3.27 & 5.39 & 4.11 & 4.35 & 5.24 & 4.96 & 1 & 0.469 & 0.137 & 0.811 & 22 \\
\hline
\end{tabular}




\begin{tabular}{|c|c|c|}
\hline 辛 & $\omega \% \mathbb{~}$ & \\
\hline के & 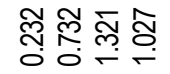 & \\
\hline 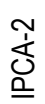 & 导 đ্ֶু & \\
\hline 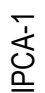 & 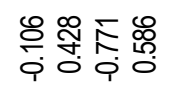 & \\
\hline 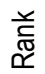 & 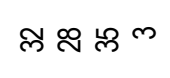 & \\
\hline 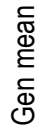 & 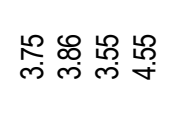 & \\
\hline 오 & 岛 & 点 象 \\
\hline ๘ & ల్లో & ঢ̄ \\
\hline 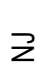 & 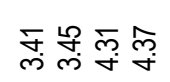 & ஜ \\
\hline$\stackrel{\bar{I}}{\Sigma}$ & 艿 ্ָণ & 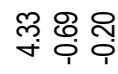 \\
\hline 产 & 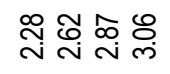 & هั \\
\hline$\sum_{j}^{\frac{\pi}{3}}$ & 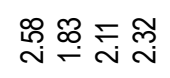 & 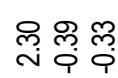 \\
\hline ⿳亠丷冖 & 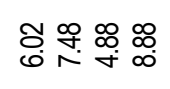 & 苗守 \\
\hline$\frac{\alpha}{<}$ & 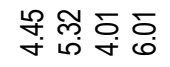 & 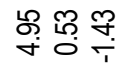 \\
\hline 足 & 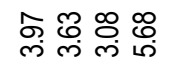 & 웅응 훙 \\
\hline$\vec{z}$ & 足 品 & 导 స్ু \\
\hline 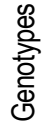 & 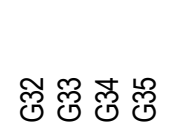 & 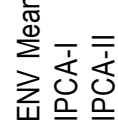 \\
\hline
\end{tabular}

prediction assessment indicated that AMMI model, with only two IPCA, was the best predictive model (Yan et al., 2002).

AMMI-1 biplot for grain yield of 35 wheat genotypes and ten locations plotted from the main effect against IPCA-1 scores of the genotypes and environment are presented in Figure 1. The IPCA-1 scores ranged from 1.472 down to -1.656 ; and grain yield means from 2.83 up to $6.93 \mathrm{t} \mathrm{ha}^{-1}$, which explained $87.6 \%$ of the total sum of square. Locations were dispersed widely in all quadrants, more than the genotypes in the biplot (Fig. 1). The lowest IPCA-1 values were scored by G11, G22 and G30. However, these genotypes scored lower grain yields across tested locations than G31, G18 and G35. On the other hand, G13, G29 and G34 scored the highest IPCA-1 and were nonstable, except for G34. The other genotypes showed better grain yield performance across the locations (Table 4).

All location and genotypes having the same sign of IPCA-1 score, interacted with each other positively, and different IPCA-1 score signs interacted negatively (Yan et al., 2002). Therefore, Bekoji, Areka, Kulumsa, Adet, Sinana and Holeta interacted positively with the highest yielding genotypes G31, G18 and G35; and negatively with G11, G16 and G34. Njoro negatively interacted with the high yielding genotypes, across locations. This made it complicated to develop high yielding and stable varieties for the two countries (Fig. 1).

In addition, AMMI-2 biplot generated by using the first two interaction principal component axes (IPCA 1 and 2) used to visual interpretation of the GEI patterns and identify genotypes or locations that exhibit low, medium or high levels of interaction effects (Yan, 2002). Accordingly, Areka, Njoro, Holeta and Bekoji were the most discriminating environments among the genotypes evaluated, as indicated by the longer vectors projected from the origin, indicating that these locations gave good information among genotypes. On the contrary; Sinana, Adet, Jama and Mehoni identified, as a least interactive environment with the tested genotypes, indicated lower interaction of these locations with the genotypes evaluated. Njoro had a different environment from any of the tested locations from Ethiopian (Fig. 2). 


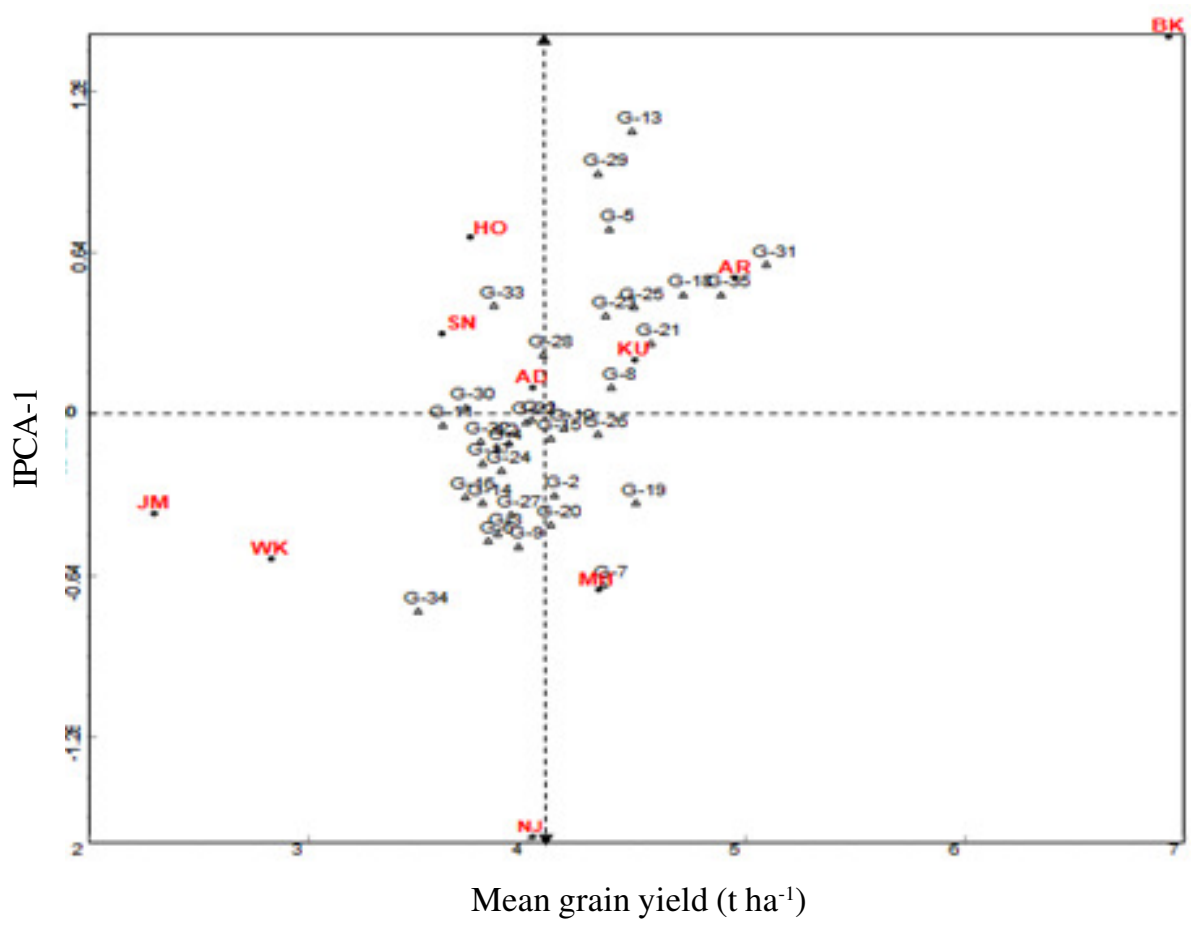

Figure 1. AMMI-1 biplot for grain yield of 35 wheat genotypes evaluated in Ethiopia and Kenya.

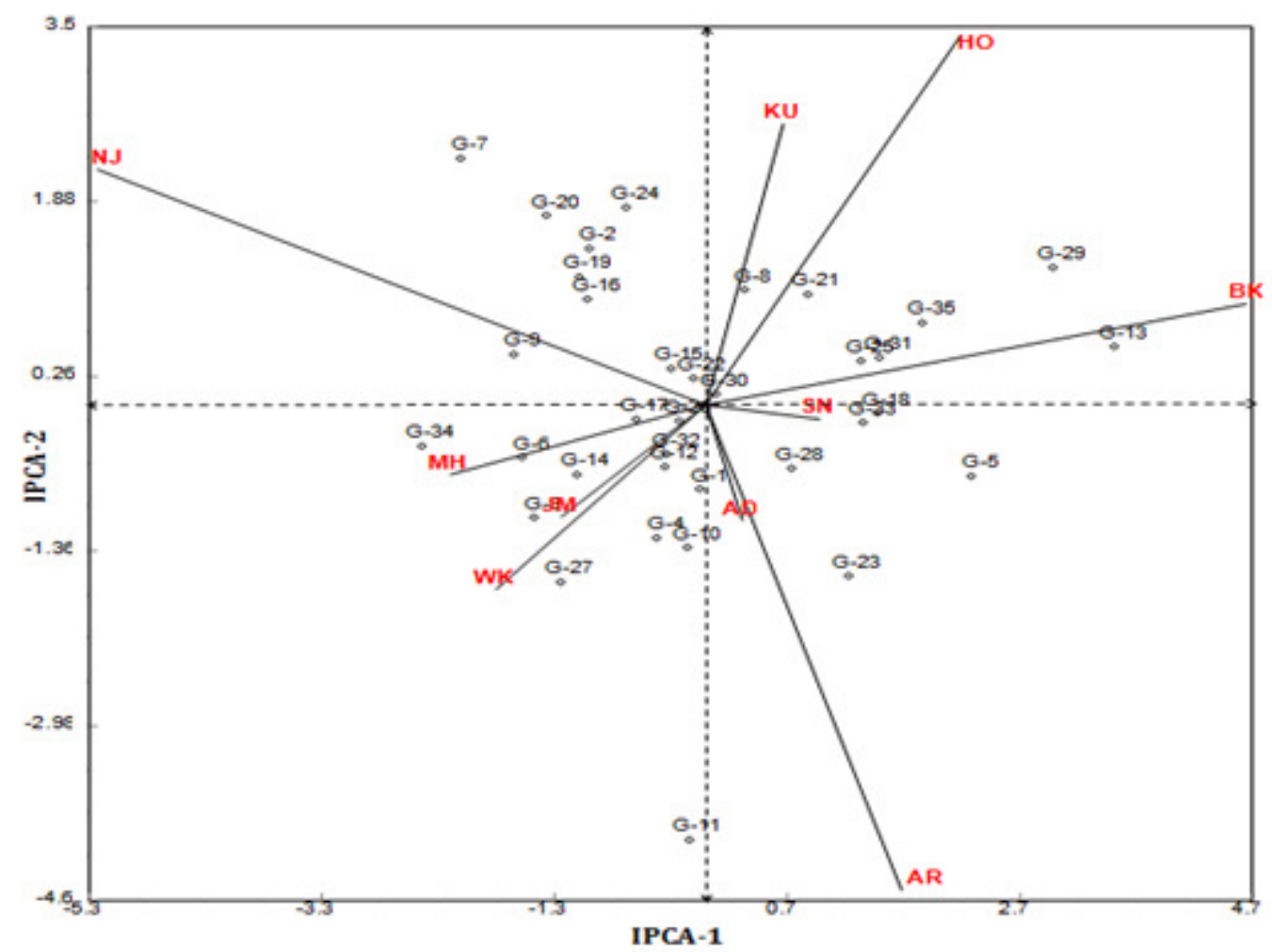

Figure 2. AMMI-2 interaction biplots for grain yield of 35 wheat genotypes tested in Ethiopia and Kenya. 
Genotypes near the origin were non-sensitive to environmental interactive forces; and those distant from the origin were sensitive and had large interactions (Samonte et al., 2005). Accordingly, genotypes G30, G26, G22 and G15 are non-sensitive to environmental interactive forces; and hence, these genotypes are considered as stable genotypes. Whereas G11, G7, G29 and G13 were highly influenced by the interactive force of environment and sensitive to environmental changes, so these varieties were considered as unstable genotypes due to the long projections from the origin (Fig. 2).

AMMI stability value (ASV). Genotypes with least ASV scores were more stable than those with higher ASV (Purchase et al., 2000). Accordingly, genotypes with small ASV values i.e. G30, G22 and G26, were found to be stable, except G26. All the genotypes had low grain yield performance across locations (Table 4). The most unstable genotypes according to the ASV approach were G13, G29 and G7, having high ASV values. However, these genotypes had above average grain yield potentials. Therefore, genotypes having high ASV correlated with high yield performance and those with low ASV correlated with low yield potential.

\section{CONCLUSION}

GEI between tested locations across Ethiopian and Kenyan were very high. It will be difficult to develop high yielding and widely adaptable varieties common to both countries sine the interaction is inconsistent. More locations should be sampled for more than two years of testing to generate general conclusion or to recommend specific adaptation. In addition, developing the same genetic background varieties for the region could have its own negative impact.

\section{ACKNOWLEDGEMENT}

This work was financially supported by the Eastern Africa Agricultural Productivity Project (EAAPP). The authors acknowledge the collaborative research institutions in Ethiopia, Tanzania and Kenya for supporting the field and data management. The Association for Strengthening Agricultural Research in Eastern and Central Africa (ASARECA) facilitated the publication of this paper.

\section{REFERENCES}

Ali, A. 2006. Genetic variation for and correlation among yield traits of wheat under irrigated and rainfedbenvironments. M.Sc. Thesis. Department of Plant Breeding and Genetics, Agric. Univ. Peshawar, Pakistan.

Amin, M., Mohammad, T. Khan, A.J., Irfaq, M., Ali, A. and Tahir, G.R. 2005. Yield stability of spring wheat (Triticum aestivum L.) in the Khyber Pukhtunkhwa, Pakistan. Songklanakarin Journal of Science Technolology 27(6):1147-1150.

Ceccarelli, S., Grando, S., Singh, M., Michael, M., Shikho, A., Al-Issa, M., Al-Saleh, A., Kaleonjy, G., Al-Ghanem, S.M., Al-Hasan, A.L., Dalla, H., Basha, S. and Basha, T. 2003. A methodological study on participatory barley breeding. II. Response to selection. Euphytica 133:185-200.

Cotes, J.M., Crossa, J., Sanches, A. and Cornelius, P.L. 2006. A Bayesian approach for assessing the stability of genotypes. Crop Science 46: 2654-2665.

FAOSTAT. 2014. Statistical Database of the Food and Agriculture of the United Nations.

Gauch, H.G. and Zobel, R.W. 1997. Identifying mega-environments and targeting genotypes. Crop Science 37(2): 311-326.

Hailu Gebre-Mariam, Tanner, D.G., and Mengistu Hulluka (Eds.). 1991. Wheat Research in Ethiopia: A historical perspective. Addis Ababa: IAR/CIMMYT.

Purchase, J.L. 1997. Parametric analysis to describe Genotype x Environment interaction and yield stability in winter wheat. Ph.D. Thesis, Department of Agronomy, Faculty of Agriculture, University of the Free State, Bloemfontein, South Africa.

Purchase, J.L., Hatting, H. and Van de venter, C.S. 2000. Genotype by environments interaction of wheat in South Africa: Stability analysis of yield performance. South Africa Journal of Plant Science 17:101-107. 
Samonte, S.O.P.B., Wilson, L.T., McClung, A.M. Yan, W., Hunt, L.A., Sheng, Q. and Szlavnics, Z. and Medley, J.C. 2005. Targeting cultivars on 2000. Cultivar evaluation and mega to rice growing environments using AMMI environment investigation based on the GGE and SREG GGE biplot analyses. Crop Science 45:2414-2424.

Yan, W. 2002. Singular-value partition for biplot analysis of multi-environment trial data. Agronomy Journal 94:990-996. biplot. Crop Science 40: 597-605.

Zobel, R.W., Wright, M.J. and Gauch, Jr. H.G. 1988. Statistical analysis of a yield trial. Agronomy Journal 80: 388-393. 